\title{
Pengembangan Matrik Lepas Lambat Berbasis EC - PVP K30 Menggunakan Teknik Dispersi Solida Dengan Model Obat Natrium Diklofenak
}

\author{
Yulistia Budianti Soemarie ${ }^{1}$, Arina Swastika Maulita ${ }^{2}$ \\ ${ }^{1}$ SMKN 17 Samarinda (Jurusan Farmasi) \\ ${ }^{2}$ Program Studi Farmasi Ilmu Kesehatan Universitas Muhammadiyah Malang
}

\begin{abstract}
This research is a modification of controlled release which beneficially to optimize the medicine reaction and to minimize the fluctuation of blood level in a certain period of the release. The aim of research is to develop the matrix system in ethylcellulose basic PVP K30 which applies dispersion solid method using sodium diclofenac as sample. Resulted four formulas consist of PVP K30 percentages as follow 0\%, 5\%, 10\% and 20\%. The different percentages of PVP K30 is aimed to know the formula which produces the releasing result of ND more optimal. This research produces in each formula significant differences $(p<0,05)$. The formula whole percentages of PVP K30 10\% has completed the requirements of control release better than the other one, shown the better resistance characteristics and release profile.
\end{abstract}

Key words : Matrix System, Solid Dispersion, Ethylcellulose, PVP K30, Sodium Diclofenac

\section{ABSTRAK}

Penelitian ini adalah modifikasi terkontrol dengan manfaat meningkatkan reaksi obat dan meminimalisir fluktuasi kadar dalam darah saat pelepasannya. Tujuan penelitian ini adalah mengembangkan sistem matrik dalam etilselulosa dasar PVP K30 dengan menerapkan metode dispersi padat menggunakan sampel sodium diklofenac. Formula PVP K30 dengan persentase 0\%, 5\%, 10\% dan 20\%. Perbedaan persentase PVP K30 tersebut ditujukan untuk mengetahui kadar yang paling optimal melepaskan sodium diclofenac. Hasil yang didapatkan diketahui bahwa kadar 10\% adalah kadar yang paling baik dalam proses pelepasan dibandingkan kadar yang lain.

Kata Kunci: sistem matriks, dispersi padat, etilselulosa,VP K30, Sodium Diclofenac

\section{PENDAHULUAN}

Bentuk sediaan lepas lambat banyak mendapat perhatian karena selain dapat mengurangi efek samping, juga dapat memberikan fungsi lain yaitu mengurangi atau menjarangkan jumlah penggunaan, mengurangi fluktuasi kadar obat dan secara umum dapat meningkatkan kenyamanan bagi pasien (Welling, 1997).

Tujuan dasar dari rancangan bentuk sediaan obat adalah untuk mengoptimalkan penyampaian obat dan untuk mengurangi fluktuasi kadar obat darah dalam periode 
waktu tertentu selama pelepasan obat berlangsung. Dengan demikian akan diperoleh hasil terapi yang efektif dan aman. Bentuk sediaan lepas lambat merupakan bentuk sediaan obat yang dirancang untuk memenuhi tujuan tersebut. Pada sediaan lepas lambat pelepasan obat dari sediaan terjadi secara bertahap dan terus menerus untuk periode waktu tertentu.

Sediaan lepas lambat yang ideal dirancang untuk dapat melepaskan suatu dosis terapeutik awal untuk menghasilkan efek terapeutik yang diinginkan secara cepat, dan diikuti pelepasan dosis penjagaan yang lebih lambat dan konstan untuk mempertahankan efek terapeutik selama periode waktu tertentu, misalnya $12-24$ jam. Dengan adanya pelepasan yang konstan tersebut maka terjadinya fluktuasi kadar obat dalam plasma dapat dihindari.

Metode umum yang digunakan untuk membuat sediaan lepas lambat adalah sistem matrik, sistem membran polimer dan sistem pompa osmotik. Pembuatan matrik sediaan lepas lambat untuk obat yang mudah larut dalam air umumnya lebih sesuai jika digunakan polimer-polimer hidrofobik, karena polimer hidrofobik dapat mencegah atau mengurangi larutan media disolusi yang berpenetrasi kedalam sistem matrik sehingga proses difusi obat akan berjalan dengan lambat. Sedangkan matrik hidrofilik umumnya tidak sesuai sebagai matrik lepas lambat untuk obat yang mudah larut dalam air karena media disolusi mudah berpenetrasi kedalam matrik sehingga akan terjadi difusi yang cepat dari bahan obat terlarut melewati jaringan gel hidrofilik yang terbentuk dari matrik (Reddy Dkk, 2003).

Penggunaan EC sebagai pembentuk matrik lepas lambat, diketahui matrik akan mengalami relaksasi. Hal ini karena EC walaupun hidrofobik namun masih dapat berinteraksi dengan air, dimana relaksasi tersebut menyebabkan sistem terdisintegrasi. Hal ini menyebabkan pelepasan bahan aktif tidak lepas lambat (Agrawal Dkk, 2003 dan Wicaksono, 2005).

Relaksasi EC dalam sistem matrik dapat diturunkan apabila EC dikombinasi dengan PVP K30 (Wicaksono, 2005). PVP didalam matrik akan meningkatkan kekerasan matrik sehingga porositas matrik menurun. Hal ini menyebabkan disintegrasi matrik pada uji disolusi tidak terjadi.

Dari penelitian lain disebutkan bahwa metode pembuatan matrik EC dengan teknik dispersi solida juga dapat membentuk sistem lepas lambat (Iqbal, Z Dkk, 2003 dan Sadeghi Dkk, 2003). Bahkan diketahui bahwa dengan teknik dispersi solida, jumlah polimer EC yang diperlukan 33\% lebih sedikit jika dibandingkan dengan teknik granulasi basah (Iqbal, Barbar dan Ashraf, 2002).

Berdasarkan uraian tersebut diatas maka dalam proposal penelitian ini akan diteliti pengembangan sediaan lepas lambat sistem matrik berbasis EC - PVP K30 menggunakan teknik dispersi solida. Sebagai model obat digunakan natrium diklofenak (ND) karena mempunyai sifat-sifat antara lain : (1) waktu paruh pendek, (2) dosis terapi kecil, dan (3) tidak memiliki masalah dalam absorpsi sehingga memenuhi persyaratan untuk diformulasi menjadi sediaan lepas lambat.

\section{METODOLOGI PENELITIAN}

\section{Alat}

Alat-alat yang digunakan dalam penelitian ini adalah Spektrofotometer UVvis, Neraca analitik, Alat uji dissolusi, Lemari pengering, Sieve analyzer, Alat penguji kadar lembab granul, PH meter, waterbath, Mortir dan stamper dan Alat-alat 
kaca yang umum digunakan dalam laboratorium.

Bahan

Bahan-bahan yang digunakan dalam penelitian ini adalah Natrium diklofenak (PT. Kimia Farma), Etil selulosa 10 Cps, PVP K30 (PT. Coronet Crown), Natrium fosfat tribasik(Merck), Etanol $96 \%$, Aqua destilata.

\section{Tempat Penelitian}

Penelitian dilakukan di

Laboratorium Teknologi Farmasi Bagian

Farmasetika Program Studi Farmasi

Universitas Jember

\section{Prosedur}

Dalam penelitian ini dibuat beberapa formula untuk membuat matrik dengan teknik dispersi solida dari ND dengan menggunakan EC dan PVP K30. Susunan formula dapat dilihat dalam Tabel 1 :

\section{Pembuatan Matrik dengan Teknik}

\section{Dispersi Solida}

Dilakukan teknik dispersi solida dengan metode penguapan pelarut antara ND, EC dan PVP K30 dengan cara sebagai berikut : ND, EC dan PVP K30 dicampur sampai homogen dalam mortir, kemudian ditambahkan etanol $96 \%$ sedikit demi sedikit sampai melarutkan campuran tersebut. Campuran kemudian dikeringkan dengan oven pada suhu $60^{\circ} \mathrm{C}$. Matrik dispersi solida kemudian direduksi ukurannya dan diayak dengan pengayak ukuran mesh 20 dan ditampung dengan pengayak ukuran mesh 80.

\section{Penentuan Kadar Lembab Matrik}

Kadar lembab ditentukan dengan alat Ohaus MB 200 dengan cara sebagai berikut

Piringan tempat bahan dari alat dibersihkan dan ditara. Sejumlah tertentu matrik ( \pm 5 gram) diletakkan diatas piringan alat. Kemudian alat dinyalakan pada suhu $100^{\circ} \mathrm{C}$ selama 10 menit. Diakhiri pemerikasaan kadar lembab matrik yang dapat dibaca pada layar alat. Persyaratan kadar lembab matrik yang ditentukan dengan 2\% - 4\% (Rani dan Mishra, 2004).

\section{Pembuatan Kurva Baku ND dalam Etanol $96 \%$}

Dari larutan baku induk ND dalam etanol $96 \%$ dibuat pengenceran sehingga didapatkan larutan dengan konsentrasi kurang lebih 5 ppm; 10 ppm; 15 ppm; 20 ppm dan 25 ppm. Masing-masing larutan kemudian ditentukan serapannya dengan spektrofotometer pada panjang gelombang maksimum yang telah didapat sebelumnya. Kemudian dibuat kurva baku dari hasil pengukuran tersebut.

\section{Penentuan Kadar ND dalam Matrik}

Penentuan kadar ND dalam matrik dilakukan sebagai berikut : ditimbang sejumlah tertentu matrik yang diperkirakan mengandung ND sekitar $25 \mathrm{mg}$. Matrik dimasukkan kedalam labu ukur $100 \mathrm{~mL}$ dan ditambah etanol $96 \% \pm 50 \mathrm{~mL}$, labu dikocok sampai granul larut semua. Kemudian ditambahkan etanol 96\% sampai garis tanda, dikocok sampai homogen. Larutan ini mengandung $\pm 25 \mu \mathrm{g} \mathrm{ND} / \mathrm{mL}$ ( $\pm 25 \mathrm{ppm}$ ). Diamati serapannya dengan spektrofotometer pada panjang gelombang maksimum. Dihitung kadar ND dengan menggunakan kurva baku ND dalam etanol $96 \%$.

\section{Pengujian Pelepasan ND dari Matrik \\ Profil pelepasan ND dari matrik ditentukan secara in vitro dengan uji disolusi menggunakan media dapar fosfat $\mathrm{pH} 6,8$}


selama 8 jam. Tahap-tahapnya adalah sebagai berikut :

\section{Pembuatan Dapar Fosfat pH 6,8}

Pembuatan dapar fosfat $\mathrm{pH} 6,8$ dilakukan dengan cara sebagai berikut : dilarutkan 76 gram natrium fosfat tribasik dalam air sehingga dihasilkan $1000 \mathrm{ml}$ larutan. Diambil dari larutan tersebut sebanyak $250 \mathrm{ml}$ kemudian dicampurkan dengan $750 \mathrm{ml}$ larutan HCL $0,1 \mathrm{~N}$ dan dilakukan adjust dengan larutan HCL $2 \mathrm{~N}$ atau larutan $\mathrm{NaOH} 2 \mathrm{~N}$ sehingga didapatkan pH $6,8 \pm 0,05$

\section{Penentuan Panjang Gelombang Maksimum ND dalam Dapar Fosfat pH 6,8}

Prosedur penentuan panjang gelombang maksimum ND dalam dapar fosfat $\mathrm{pH}$ 6,8 sama dengan prosedur penentuan panjang gelombang maksimum ND dalam etanol $96 \%$, dimana pelarut yang digunakan diganti dengan menggunakan larutan dapar fosfat $\mathrm{pH} 6,8$.

\section{Pembuatan Kurva Baku ND dalam Dapar Fosfat pH 6,8}

Prosedur pembuatan kurva baku ND dalam dapar fosfat $\mathrm{pH}$ 6,8 sama dengan prosedur pembuatan kurva baku ND dalam etanol 96\%, dimana pelarut yang digunakan diganti dengan dapar fosfat $\mathrm{pH} 6,8$.

\section{Uji Pelepasan ND dari Matrik}

Uji disolusi dari matrik dilakukan dengan media dapar fosfat $\mathrm{pH} 6,8 \pm 0,05$ selama 8 jam. Peralatan yang digunakan tipe 1 (konstruksi basket, kecepatan putaran 50 rpm). Prosedur yang dilakukan adalah sebagai berikut :

Dimasukkan air dalam bak alat uji dissolusi sampai tanda, dipasang labu disolusi dan diisi dengan $900 \mathrm{ml}$ media disolusi (dapar fosfat $\mathrm{pH}$ 6,8). Ditentukan suhu, waktu dan kecepatan putaran basket uji disolusi yaitu pada $37 \pm 0,5^{\circ} \mathrm{C}$ selama 8 jam dengan kecepatan putaran $50 \mathrm{rpm}$. Setelah suhu stabil dispersi solida dengan kandungan ND $100 \mathrm{mg}$ dimasukkan kedalam labu disolusi dan alat uji disolusi dijalankan. Sampling dilakukan pada waktu $1 / 2,1,2,3,4,6$, dan 8 jam dengan cara mengambil 5,0 $\mathrm{ml}$ larutan media disolusi. Untuk setiap kali selesai sampling dilakukan penambahan 5,0 $\mathrm{ml}$ larutan media yang baru (Bravo, Lamas dan Salomon, 2002). Tentukan serapan sampel dengan spektrofotometer pada panjang gelombang maksimum. Dihitung kadar ND untuk setiap sampel dan dibuat kurva \% pelepasan ND - waktu.

\section{Analisis Data Hasil Uji Pelepasan Natrium Diklofenak}

Data hasil uji pelepasan natrium diklofenak kemudian dianalisis dengan tahap-tahap sebagai berikut :

Analisis Kesesuaian Pelepasan dengan

Persyaratan Pelepasan Sediaan Lepas Lambat

Kesesuaian pelepasan masing-masing formula untuk sediaan lepas lambat ditentukan dengan menggunakan ketentuan sebagai berikut (Banakar, 1992) :

- Pada waktu sebanding 0,25 D : jumlah obat yang dilepaskan 20$50 \%$

- Pada waktu sebanding 0,5 D : jumlah obat yang dilepaskan 45 $75 \%$

Keterangan : $\mathrm{D}=$ interval pemakaian 
Analisis Perbedaan Kadar Lembab Matrik dan Pelepasan Na Diklofenak dari Masing-masing Formula Secara Statistik.

Untuk mengetahui perbedaan pada pengujian kadar lembab dan uji pelepasan ND dari matrik yang signifikan atau tidak secara statistik maka dilakukan uji anova. Uji kadar lembab matrik dan uji pelepasan dianggap berbeda signifikan jika nilai $\mathrm{p}<0,05$ dan tidak signifikan jika nilai $p>0,05$. Untuk uji pelepasan, yang diuji adalah pelepasan ND pada $\mathrm{t} 3$ jam dan $\mathrm{t} 6$ jam (Rani dan Mishra, 2004).

\section{HASIL PENELITIAN}

Hasil Pembuatan Matrik F1, F2, F3 dan F4

Matrik dibuat dengan metode dispersi solida. Jumlah masing - masing bahan yang ditimbang dapat dilihat pada Tabel 2 .

\section{Hasil Penentuan Distribusi Ukuran} Matrik

Penentuan distribusi ukuran matrik dilakukan dengan menggunakan alat sieve shaker. Hasil penentuan distribusi ukuran matrik F1, F2, F3 dan F4 dapat dilihat pada Tabel 3 dan Gambar 1.

\section{Hasil Penentuan Kadar Lembab Matrik}

Penentuan kadar lembab matrik dilakukan dengan alat Ohaus MB200. Hasil penentuan kadar lembab dapat dilihat pada Tabel 4.

\section{Hasil Pembuatan Kurva Baku ND dalam Etanol 96\%}

Pembuatan kurva baku ND dalam etanol $96 \%$ dilakukan dengan cara mengukur serapan beberapa larutan ND dalam etanol $96 \%$ yang memiliki kadar yang berbeda (suatu seri pengenceran). Hasil pengukuran serapan larutan ND dalam etanol 96\% dapat dilihat pada Tabel 5 .

\section{Hasil Penentuan Kadar ND dalam Matrik \\ Penentuan kadar ND matrik} dilakukan dengan cara melarutkan sejumlah tertentu matrik dalam etanol $96 \%$ dan dilakukan pengenceran sehingga didapatkan kadar ND \pm 25 ppm. Kadar ND ditentukan dengan cara mengukur serapan larutan ND dengan spektrofotometer dan membandingkannya dengan kurva baku. Hasil penentuan kadar ND dalam matrik F1, F2, F3 dan F4 dapat dilihat pada Tabel 6.

\section{Hasil Pengujian Pelepasan ND dari Matrik}

Hasil Profil pengujian pelepasan ND dari matrik ditentukan secara in vitro dengan uji disolusi menggunakan media dapar fosfat pH 6,8 selama 8 jam.

\section{Hasil Pembuatan Kurva Baku ND dalam Dapar Fosfat pH 6,8}

Kurva baku ND dalam dapar fosfat pH 6,8 dibuat dengan mengukur serapan suatu seri pengenceran larutan ND dalam dapar fosfat $\mathrm{pH}$ 6,8. Hasil pengukuran serapan suatu seri larutan ND dan pembuatan kurva baku ND dalam dapar fosfat $\mathrm{pH}$ 6,8 dapat dilihat pada Tabel 7.

\section{Hasil Uji Pelepasan ND dari Matrik}

Hasil uji pelepasan dari matrik F1, F2, F3 dan F4 dapat dilihat pada Tabel 8 dan Gambar 2.

\section{Hasil Analisis Pelepasan ND dari Matrik} Hasil analisis kesesuaian pelepasan ND dengan persyaratan pelepasan matrik. Hasil analisis kesesuaian pelepasan ND dengan 
Tabel 1 Susunan Formula Matrik dari ND Menggunakan EC dan PVP K30

\begin{tabular}{lcccc}
\hline \multicolumn{1}{c}{ Bahan } & F1 (mg) & F2 (mg) & F3 (mg) & F4 (mg) \\
\hline Natrium Diklofenak & 100 & 100 & 100 & 100 \\
Etil Selulosa & 300 & 300 & 300 & 300 \\
PVP K30 & $0 \%$ & $5 \%$ & $10 \%$ & $20 \%$ \\
\hline
\end{tabular}

Tabel 2. Penimbangan Bahan Untuk Pembuatan Matrik Sebanyak 300 Unit Dosis

\begin{tabular}{lcccc}
\hline \multirow{2}{*}{ Bahan } & \multicolumn{4}{c}{ Formula } \\
\cline { 2 - 5 } & 1 & 2 & 3 & 4 \\
\hline Natrium diklofenak & $30,0710 \mathrm{~g}$ & $30,0613 \mathrm{~g}$ & $30,1105 \mathrm{~g}$ & $30,0834 \mathrm{~g}$ \\
Etil selulosa & $90,0634 \mathrm{~g}$ & $90,0389 \mathrm{~g}$ & $90,0248 \mathrm{~g}$ & $90,0174 \mathrm{~g}$ \\
PVP K30 & - & $4,5359 \mathrm{~g}$ & $9,0111 \mathrm{~g}$ & $18,0598 \mathrm{~g}$ \\
Etanol 96\% & $382 \mathrm{ml}$ & $430 \mathrm{ml}$ & $440 \mathrm{ml}$ & $472 \mathrm{ml}$ \\
\hline
\end{tabular}

Matrik dibuat untuk 300 formula.

Tabel 3 Hasil Penentuan Distribusi Ukuran Matrik F1, F2, F3 dan F4

\begin{tabular}{cccccc}
\hline Formula & Mesh 20 & Mesh 40 & Mesh 60 & Mesh 80 & Fines \\
\cline { 2 - 6 } & \multicolumn{5}{c}{ Rata - rata (gram) \pm RSD } \\
\hline F1 & $12,606 \pm 0,04$ & $24,689 \pm 0,04$ & $28,695 \pm 0,03$ & $14,440 \pm 0,04$ & $24,502 \pm 0,02$ \\
F2 & $21,269 \pm 0,1$ & $24,444 \pm 0,05$ & $29,332 \pm 0,1$ & $14,168 \pm 0,03$ & $23,085 \pm 0,03$ \\
F3 & $25,824 \pm 0,03$ & $27,696 \pm 0,08$ & $24,182 \pm 0,02$ & $10,398 \pm 0,02$ & $24,869 \pm 0,01$ \\
F4 & $10,889 \pm 0,02$ & $20,671 \pm 0,03$ & $37,915 \pm 0,04$ & $18,419 \pm 0,02$ & $35,220 \pm 0,01$ \\
\hline
\end{tabular}

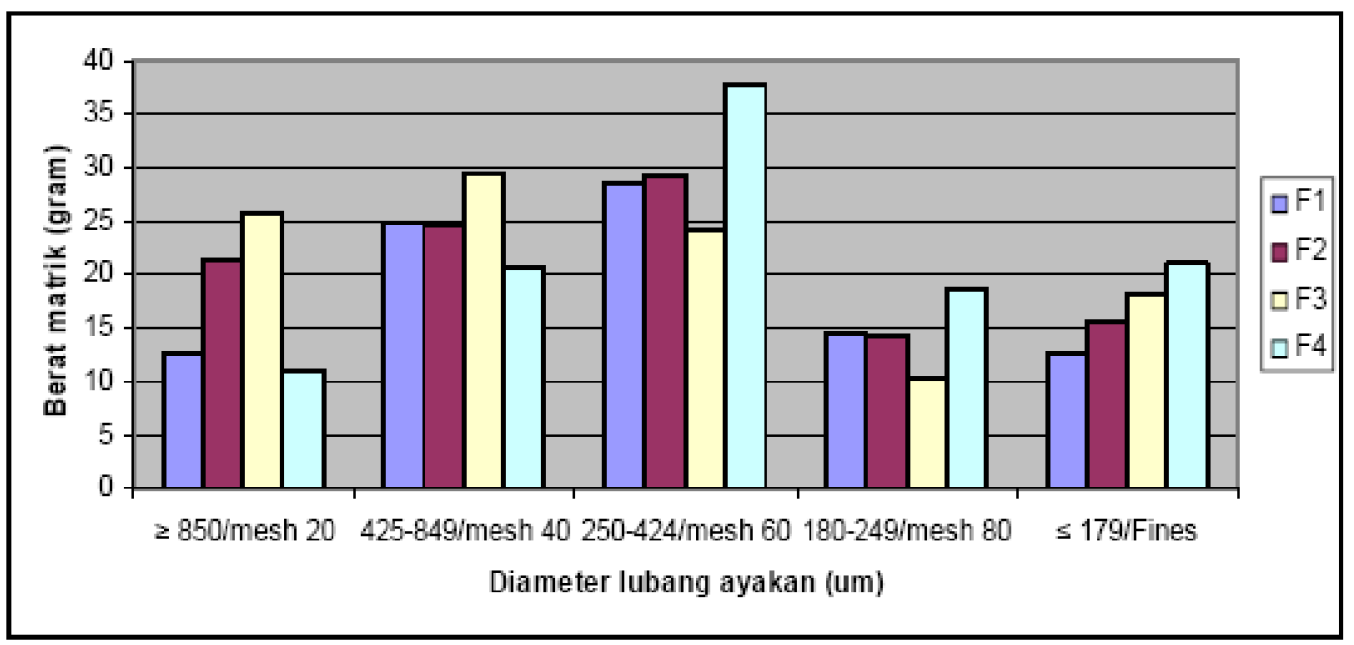

Gambar 1. Histogram Dari Distribusi Ukuran Matrik F1, F2, F3 dan F4. 
Tabe1 4 Hasil Penentuan Kadar Lembab Matrik F1, F2, F3 dan F4.

Penentuan Kadar Lembab dilakukan dengan Replikasi 3 Kali.

\begin{tabular}{ccc}
\hline No. & Formula & Kadar lembab \pm RSD \\
\hline 1 & F1 & $1,47 \pm 0,08$ \\
2 & F2 & $1,53 \pm 0,08$ \\
3 & F3 & $1,67 \pm 0,07$ \\
4 & F4 & $2,2 \pm 0,00$ \\
\hline
\end{tabular}

Tabel 5 Hasil Pengkuran Serapan Larutan ND dalam Etanol 96\% dengan Suatu Seri Pengenceran

\begin{tabular}{cc}
\hline Konsentrasi Na diklofenak $(\mathrm{ppm})$ & Absorbansi \\
\hline 5,04 & 0,167 \\
10,08 & 0,372 \\
15,36 & 0,568 \\
20,48 & 0,771 \\
25,2 & 0,921 \\
\hline
\end{tabular}

Tabel 6 Hasil Penentuan Kadar ND Matrik F1, F2, F3 dan F4.

Penentuan Kadar ND dilakukan dengan Replikasi 3 Kali.

\begin{tabular}{cccc}
\hline No & Formula & Kadar ND(ppm) \pm RSD & \% Recovery ND \pm RSD \\
\hline 1. & F1 & $15,315 \pm 0,05$ & $146,183 \pm 0,05$ \\
2. & F2 & $10,892 \pm 0,07$ & $107,211 \pm 0,02$ \\
3. & F3 & $12,363 \pm 0,04$ & $118,252 \pm 0,05$ \\
4 & F4 & $10,688 \pm 0,01$ & $101,169 \pm 0,06$ \\
\hline
\end{tabular}

Tabel.7 Serapan Ultraviolet Larutan ND dalam Dapar Fosfat $\mathrm{pH} 6,8$

\begin{tabular}{cc}
\hline Konsentrasi ND (ppm) & Absorbansi \\
\hline 10,16 & 0,257 \\
15,36 & 0,382 \\
20,48 & 0,507 \\
25,4 & 0,65 \\
30,72 & 0,78 \\
\hline
\end{tabular}

Tabel 8 Hasil Uji Pelepasan ND dari Matrik F1, F2, F3 dan F4.

\begin{tabular}{cccccccc}
\hline Formula & \multicolumn{7}{c}{$\begin{array}{c}\% \\
\text { pelepasan pada } \text { Rata-rata } \pm \text { RSD }\end{array}$} \\
& \multicolumn{7}{c}{ Renit) } \\
& 30 & 60 & 120 & 180 & 240 & 360 & 480 \\
\hline F1 & 25,109 & 37,711 & 62,126 & 63,636 & 68,341 & 77,465 & 85,109 \\
& $\pm 0,03$ & $\pm 0,05$ & $\pm 0,03$ & $\pm 0,03$ & $\pm 0,02$ & $\pm 0,05$ & $\pm 0,03$ \\
F2 & 9,246 & 12,434 & 18,413 & 21,912 & 24,791 & 29,625 & 31,479 \\
& $\pm 0,07$ & $\pm 0,04$ & $\pm 0,10$ & $\pm 0,03$ & $\pm 0,05$ & $\pm 0,04$ & $\pm 0,07$ \\
F3 & 19,029 & 22,132 & 32,412 & 34,163 & 39,954 & 45,701 & 46,605 \\
& $\pm 0,04$ & $\pm 0,15$ & $\pm 0,02$ & $\pm 0,07$ & $\pm 0,10$ & $\pm 0,07$ & $\pm 0,05$ \\
F4 & 37,831 & 44,898 & 50,956 & 52,088 & 55,766 & 60,482 & 63,482 \\
& $\pm 0,10$ & $\pm 0,05$ & $\pm 0,02$ & $\pm 0,02$ & $\pm 0,04$ & $\pm 0,05$ & $\pm 0,07$ \\
\hline
\end{tabular}


persyaratan pelepasan matrik dapat dilihat pada Tabel 9.

\section{PEMBAHASAN}

Dalam penelitian yang bersifat eksperimental laboratoris ini, dilakukan pengembangan matrik lepas lambat berbasis

EC dan PVP K30 menggunakan teknik dispersi solida dengan model obat natrium diklofenak. Disusun formula lepas lambat ND - EC dengan perbandingan 1:3 dan dilakukan penambahan dengan PVP K30 yang bertujuan untuk meningkatkan kekerasan matrik sehingga sifat pelepasan dari matrik memenuhi persyaratan sediaan lepas lambat. Kadar PVP K30 yang ditambahkan pada masing-masing formula berbeda-beda. Hal ini dilakukan agar didapatkan formula yang paling baik untuk sistem lepas lambat.

Proses pembuatan matrik dilakukan dengan menggunakan metode dispersi solida. Dalam metode ini, pembuatan matrik dilakukan dengan cara penguapan pelarut dan pelarut yang digunakan adalah etanol 96\%. Penguapan pelarut ini dibantu dengan oven, agar etanol yang terjebak dalam matrik ikut menguap semua. Teknik pembuatan matrik memegang peranan penting didalam proses pelepasan ND sebagai model obat karena mengatur laju pelepasan ND dari matrik. Teknik pembuatan matrik yang berbeda akan dapat menghasilkan pelepasan ND yang berbeda pula. Oleh karena itu perlakuan antar formula didalam proses pembuatan harus benar-benar sama. Matrik yang telah terbentuk akan melewati beberapa proses pengujian sebelum dilakukan uji pelepasan ND. Pengujian yang dilakukan yaitu uji distribusi ukuran matrik, uji kadar lembab, uji kandungan ND dalam matrik dan uji pelepasan ND.

Dilakukan pula uji kadar lembab matrik pada masing-masing formula F1, F2, F3 dan F4. Dimana, kadar lembab matrik di tentukan dengan range antara $2 \%$ sampai 4\%. Hasil penentuan kadar lembab matrik untuk formula F1, F2, F3 dan F4 masing masing adalah $1,47 \% \pm 0,08,1,53 \pm 0,08$ $\%, 1,67 \pm 0,07 \%, 2,2 \pm 0,0 \%$. Dari hasil penelitian didapatkan bahwa F4 merupakan formula yang memenuhi persyaratan uji kadar lembab. Hal ini dikarenakan jumlah PVP K30 yang lebih banyak dibandingkan dengan formula lainnya. Pengaruh dari penambahan PVP yang besar mengakibatkan kadar lembab F4 paling tinggi, hal ini karena PVP bersifat higroskopis sehingga menyerap air dari udara dilingkungan sekitar. Sedangkan untuk F1, F2 dan F3 tidak memenuhi persyaratan, hal ini bisa diakibatkan karena terlalu lama dilakukan penguapan pelarut di oven. Sehingga kadar air yang terdapat didalam matrik terlalu sedikit.

Berdasarkan hasil penentuan kadar ND matrik maka didapatkan \% recovery ND untuk matrik F1, F2, F3 dan F4 berturutturut adalah $146,183 \% \pm 0,05 ; 107,211 \%$ $\pm 0,02 ; 118,252 \% \pm 0,05 ; 101,169 \% \pm 0,06$. Setelah diketahui \% recovery masing masing formula maka didapatkan rata-rata matrik yang ditimbang untuk pengujian pelepasan matrik dengan dosis ND $100 \mathrm{mg}$ untuk tiap formula.

Selanjutnya dilakukan uji pelepasan matrik F1, F2, F3 dan F4 secara in vitro dengan uji disolusi dalam media dapar fosfat pH 6,8. Jumlah ND yang dilepaskan dari matrik ditentukan pada waktu 1/2, 1, 2, 3, 4, 6 dan 8 jam. Uji pelepasan matrik menggunakan dapar pH 6,8 ini bertujuan untuk melihat mekanisme pelepasan dan 


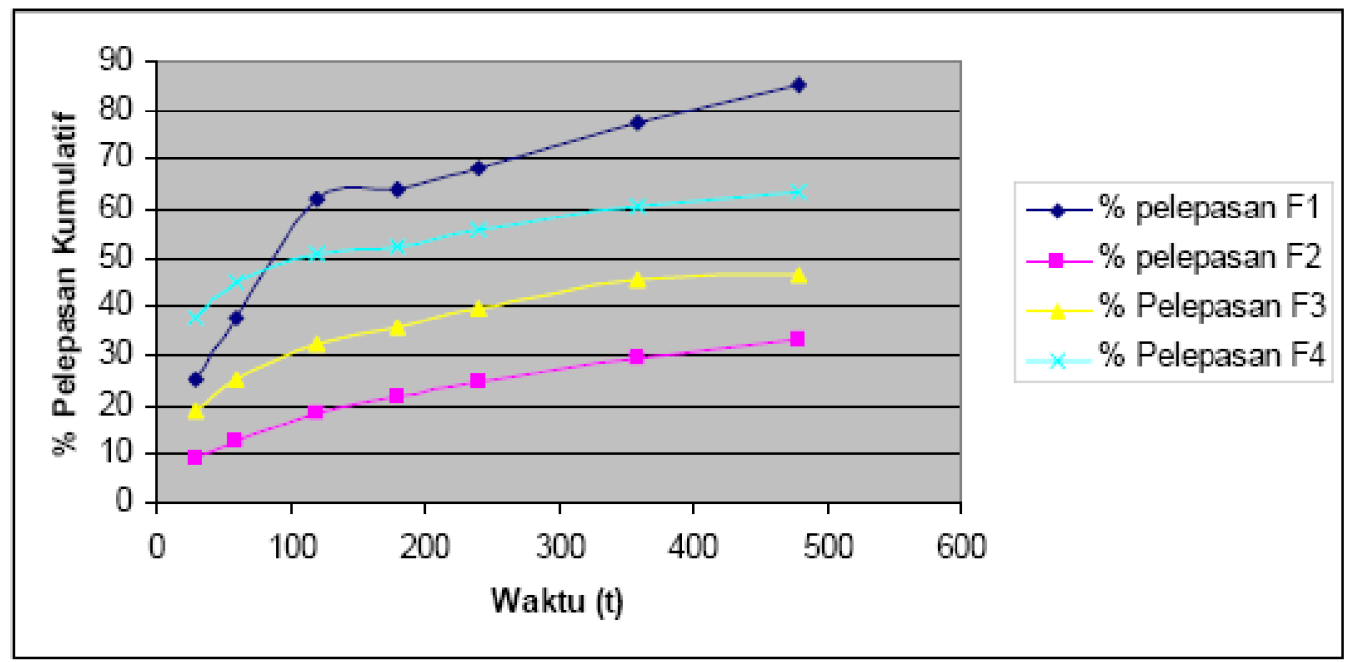

Gambar 2 Profil Pelepasan ND dari Matrik F1, F2, F3 dan F4 dalam Media Dapar Fosfat pH 6,8 $\pm 0,05$. Matrik F1, F2, F3 dan F4 Merupakan Rata-rata \pm RSD Enam Kali.

profil pelepasan ND dari matrik, dimana media dapar fosfat tersebut dikondisikan sebagai kondisi fisiologis cairan usus dari tubuh.

Persyaratan uji disolusi yang dilakukan mengacu pada PG Welling (1997) yaitu persen bahan obat terlarut pada waktu - waktu tertentu. Berdasarkan kriteria tersebut dapat diketahui formula yang memberikan pelepasan total yang ideal untuk matrik lepas lambat. Analisis kesesuaian pelepasan masing- masing formula untuk matrik lepas lambat ditentukan dengan menggunakan ketentuan dari Banakar (1992), yaitu jumlah obat yang dilepaskan berturut-turut pada t 3 jam dan t 6 jam adalah $20-50 \%$ dan $45-75 \%$.

Hasil yang didapatkan pada pengujian disolusi dalam dapar fosfat $\mathrm{pH}$ 6,8 menunjukkan bahwa semakin besar kadar PVP K30 yang ditambahkan pada tiap - tiap formula, maka semakin besar pula pelepasan ND dari matrik. Hal ini dikarenakan PVP K30 bersifat higroskopis yang akan meningkatkan kekerasan matrik setelah jangka waktu tertentu. Tetapi walaupun PVP K30 dapat meningkatkan kekerasan matrik, PVP K30 juga mudah melepaskan bahan obat dalam media disolusi. Karena PVP K30 selain memiliki sifat higroskopis juga bersifat hidrofilik, dimana dalam kadar yang besar akan lebih mudah berinteraksi dengan media disolusi. Hal ini dapat dilihat dari hasil penelitian yang didapat.

Dari data yang dihasilkan matrik F1 tidak memberikan penghambatan yang sesuai untuk suatu sediaan lepas lambat. Pelepasan ND pada t 3 jam dan t 6 jam berturut - turut adalah $63,636 \pm 0,03 \%$ dan $77,465 \pm 0,05 \%$. Hal ini dikarenakan pada formula F1 tidak ada penambahan PVP $\mathrm{K} 30$, sehingga terjadinya interaksi antara media disolusi dengan ND sangat cepat. EC sebagai basis tunggal dari matrik F1, walaupun bersifat hidrofobik tetapi masih mampu berinteraksi dengan air karena adanya gugus hidroksi yang tidak tersubtitusi. Sehingga EC tidak dapat memberikan hambatan yang baik terhadap masuknya media kedalam matrik dan mengakibatkan ND terlepas segera dari matrik.

Hasil yang didapatkan dari formula F2 juga tidak memberikan penghambatan yang baik untuk sediaan lepas lambat. 
Pelepasan ND pada t 3 jam dan t 6 jam berturut-turut adalah $21,912 \pm 0,03 \%$ dan $29,625 \pm 0,04 \%$. Dimana untuk t 3 jam masuk kedalam rentang yang dipersyaratkan $20-50 \%$, tetapi untuk t 6 jam tidak masuk kedalam rentang yang dipersyaratkan 45 $75 \%$. Hal ini dikarenakan penambahan PVP K30 dalam jumlah yang sedikit, sehingga PVP K30 tidak mampu memberikan pori pori yang cukup bagi media untuk berpenetrasi kedalam matrik EC yang menghambat pelepasan ND pada t 6 jam.

Untuk formula F3 memberikan penghambatan yang sesuai untuk sediaan lepas lambat. Pelepasan ND pada t 3 jam dan $\mathrm{t} 6$ jam berturut-turut adalah $34,163 \pm$ $0,07 \%$ dan $45,701 \pm 0,07 \%$. Hal ini sesuai dengan rentang penghambatan yang dipersyaratkan. Dari hasil yang didapat diketahui bahwa EC yang dikombinasi dengan PVP dapat menurunkan relaksasi EC didalam sistem matrik yang mengakibatkan disintegrasi matrik pada uji disolusi tidak terjadi. Karena itulah PVP mampu menghambat pelepasan ND dari matrik dengan baik. Hasil yang sama didapatkan oleh Wicaksono (2005), dimana PVP yang terdapat didalam matrik akan meningkatkan kekerasan matrik sehingga porositas matrik menurun.

Sedangkan untuk formula F4, tidak dapat memberikan penghambatan yang baik. Hal ini dikarenakan pelepasan ND pada $\mathrm{t} 3$ jam dan t 6 jam berturut - turut adalah $52,008 \pm 0,02$ dan 60,482 $\pm 0,05 \%$, karena keberadaan PVP K30 yang bersifat hidrofilik akan meningkatkan penetrasi media disolusi kedalam matrik. Penambahan PVP K30 dengan konsentrasi 20\% juga dapat membuat hambatan matrik EC rusak. Peristiwa ini dapat diketahui dengan tingkat pelepasan ND dari matrik yang tinggi. Sehingga, semakin besar kadar PVP K30 yang ditambahkan pada masing - masing formula maka proses difusi ND dari matrik akan semakin besar pula.

Dari hasil uji pelepasan ND dalam matrik F1, F2, F3 dan F4, formula F3 dipilih sebagai formula yang dapat dikembangkan untuk menjadi formula lepas lambat. Pemilihan ini didasarkan atas sifat penghambatan F3 lebih besar dari pada F1 dan F2 dan profil pelepasan F3 lebih baik dari pada F4.

Hasil uji anova untuk uji kadar lembab matrik pada F1, F2, F3 dan F4 menunjukkan bahwa hanya pada $\mathrm{F} 4$ yang memberikan hasil berbeda bermakna terhadap F1, F2 dan F3 (p<0,05). Sedangkan untuk F1, F2 dan F3 memberikan hasil tidak berbeda secara bermakna. Hal ini dapat dilihat bahwa hasil uji kadar lembab dari ketiga formula tersebut tidak berbeda jauh.

\section{DAFTAR PUSTAKA}

Agrawal,A.M., Manek,R.V., Kolling,W.M., Neau, S.H., 2003. Studies on the Interaction of Water with Ethylcellulose : Effect of Polymer Particle Size. Pharm Sci Tech 4 (4) article 60.

Banakar, U.V., 1992. Pharmaceutical Disslution Testing, Marcel Dekker Inc. New York, p.322

Bravo A.S, Lamas M.C, Salomon J.C., 2002. In Vitro Studies Of Dichlofenac Sodium Controlled Release From Biopolymeric Hydrophilic Matrices. J Pharm Sci. p.215.

Iqbal,Z., Babar,A., Ashraf,M., 2002. Controlled Release Naproxen Using Micronized Ethylcellulose by Wetgranulation and Solid-Dispersion 
(Abstract). Drug Dev and Ind Pharm,

Volume 28.

Rani,M., Mishra,B.,2004. Comparative In Vitro and In Vivo Evaluation of Matrix, Osmotic Matrix, and Osmotic Pump Tablets for Controlled Delivery of Diclofenac Sodium. Pharm Sci Tech 5(4) article 71.

Reddy, K.R., Mutalik,S., Reedy, S., 2003. Once - Daily Sustained - Release Matrix Tablet of Nicorandil : Formulation and In Vitro Evaluation. Pharm Sci Tech 4 (4).

Sadeghi, F., Garekani, H.A., M.K., 1996. Modern Pharmaceutics : Tablet Dosage Forms, Marcel Dekker Inc. New York.

Welling,P.G., 1997. Phrmanacokinetics: Processes, Mathematics, and Applications. 2"edition, Washington DC. p83.

Wicaksono, Yudi., 2005. Pengembangan Sediaan Lepas Lambat $\mathrm{Na}$ Diklofenak Berbasis Matrik Etil selulosa - PVP K30, Tidak Dipublikasikan. Tesis. Universitas Airlangga, Surabaya. 